\title{
Euphorbia adenoplicata, a New Species of Euphorbia sect. Crossadenia from Brazil
}

\author{
Authors: Marques da Silva, Otávio Luis, Antar, Guilherme Medeiros, \\ Riina, Ricarda, and Cordeiro, Inês
}

Source: Systematic Botany, 45(1) : 131-136

Published By: The American Society of Plant Taxonomists

URL: https://doi.org/10.1600/036364420X15801369352388

BioOne Complete (complete.BioOne.org) is a full-text database of 200 subscribed and open-access titles in the biological, ecological, and environmental sciences published by nonprofit societies, associations, museums, institutions, and presses.

Your use of this PDF, the BioOne Complete website, and all posted and associated content indicates your acceptance of BioOne's Terms of Use, available at www.bioone.org/terms-of-use.

Usage of BioOne Complete content is strictly limited to personal, educational, and non - commercial use. Commercial inquiries or rights and permissions requests should be directed to the individual publisher as copyright holder.

BioOne sees sustainable scholarly publishing as an inherently collaborative enterprise connecting authors, nonprofit publishers, academic institutions, research libraries, and research funders in the common goal of maximizing access to critical research. 
Systematic Botany (2020), 45(1): pp. 131-136

(c) Copyright 2020 by the American Society of Plant Taxonomists

DOI $10.1600 / 036364420 X 15801369352388$

Date of publication February 25, 2020

\title{
Euphorbia adenoplicata, a New Species of Euphorbia sect. Crossadenia from Brazil
}

\author{
Otávio Luis Marques da Silva, ${ }^{1,4}$ Guilherme Medeiros Antar, ${ }^{2}$ Ricarda Riina, ${ }^{3}$ and Inês Cordeiro ${ }^{1}$ \\ ${ }^{1}$ Núcleo de Pesquisa Curadoria do Herbário SP, Instituto de Botânica. Avenida Miguel Stéfano 3687, São Paulo, \\ CEP 04301-902, SP, Brazil \\ ${ }^{2}$ Departamento de Botânica, Instituto de Biociências, Universidade de São Paulo, Rua do Matão 277, \\ 05508-090, São Paulo, SP, Brazil \\ ${ }^{3}$ Real Jardín Botánico, RJB-CSIC, Plaza de Murillo 2, ES-28014, Madrid, Spain \\ ${ }^{4}$ Author for correspondence (otaviolmarques@gmail.com)
}

Communicating Editor: John Schenk

\begin{abstract}
A new species, Euphorbia adenoplicata, is here described and illustrated. The species was found in the vicinity of Serra Geral do Tocantins, close to the border of the states of Tocantins and Bahia, within the Cerrado biome, where it grows in cerrado rupestre (rocky savannah vegetation). Euphorbia adenoplicata is placed in Euphorbia sect. Crossadenia based on morphological characters. The species is unique within the section due to its cyathial glands with the margins folded in the middle portion, splitting each gland into two cavities. We compare the morphology and ecology of E. adenoplicata with E. sarcodes and other species of E. sect. Crossadenia subsect. Ephedropeplus. Finally, we recommend that E. adenoplicata be considered critically endangered due to its extreme rarity.
\end{abstract}

Keywords-Cerrado, cerrado rupestre, Euphorbia subgenus Chamaesyce, subsection Ephedropeplus, taxonomy, Tocantins.

Although plant collections have increased substantially in Brazil in the last $15 \mathrm{yr}$ (Morim and Lughadha 2015), there are still many poorly collected areas in the country (BFG 2015; Oliveira et al. 2017). Some of the least known areas are in Tocantins (BFG 2015), a state with most of its territory covered by the Cerrado biome, which is considered a biodiversity hotspot (Mittermeier et al. 2011; Strassburg et al. 2017). Recent expeditions to this central Brazilian state have yielded new plant records and new taxa (e.g. Devecchi and Pirani 2015; Araújo et al. 2016; Borges and Antar 2016; Moreira et al. 2017; Alves et al. 2018; Antar et al. 2018; Mendoza and Martins 2018). In the genus Euphorbia in Brazil, novelties have been published during the last decade, including new species (Carrillo-Reyes and Steinmann 2011; CarneiroTorres et al. 2012; Silva and Cordeiro 2015; Hurbath et al. 2018) and new records for the country (Külkamp et al. 2018).

Euphorbiaceae is among the richest families of the Brazilian flora, with ca. 950 species (BFG 2015; Flora do Brasil 2020 [under construction] 2019). Euphorbia, the largest genus in the family with over 2000 species (Horn et al. 2012), is represented by 63 species in Brazil, with more than $50 \%$ of them endemic to the country (Flora do Brasil 2020 [under construction] 2019). Among the four subgenera recognized in Euphorbia, Euphorbia subg. Chamaesyce is the one best represented in the New World (Yang et al. 2012) and it is also the most species-rich in Brazil (Flora do Brasil 2020 [under construction] 2019). One of the most charismatic groups within subgenus Chamaesyce in Brazil is E. sect. Crossadenia Boiss., which comprises 11 species (E. appariciana Rizzini, E. crossadenia Pax \& K.Hoffm., E. flaviana Carn.-Torres \& Cordeiro, E. goyazensis Boiss., E. gymnoclada Boiss., E. lycioides Boiss., E. riinae Steinm., E. sarcodes Boiss., E. sessilifolia Klotzsch ex Boiss., E. teres M.Machado \& Hofacker, and the new species here described). Almost all of the species are found in the northeastern and central parts of Brazil, except for E. riinae, which is endemic to eastern Santa Cruz Province in Bolivia (Yang et al. 2012; Steinmann 2013; Marques et al. 2016).

Species of Euphorbia sect. Crossadenia usually grow on rock outcrops or in sandy soils in the Caatinga and Cerrado domains. They are characterized by a herbaceous perennial or else shrubby habit; leaves that are well developed and persistent or else minute and soon deciduous; glanduliform stipules; cyathia arranged in dichasia or pleiochasia, with four or five glands, exappendiculate or bearing fimbriate, lobed, or deeply cleft appendages; and seeds with an apical extension previously thought to be a crustaceous caruncle (Yang et al. 2012; Marques et al. 2016). Although half of the currently known species of the section were described in the classical works of Boissier (1860, 1862), additional species have been recently described (Machado and Hofacker 2008; CarneiroTorres et al. 2012; Steinmann 2013). Leaf shape, number, morphology and disposition of cyathial glands appendages, and indumentum of both vegetative and reproductive structures are among the main features used to recognize species within sect. Crossadenia (Carneiro-Torres et al. 2012). In this paper, we describe a new species in this group, which we assign to E. sect. Crossadenia subsect. Ephedropeplus (Müll. Arg.) Pax based on morphological characters.

\section{Materials ANd Methods}

We examined ca. 250 collections of the species of Euphorbia sect. Crossadenia deposited in ALCB, CEN, ESA, HRB, HUEFS, MBM, RB, SP, SPF, UB, UEC, and UFG (acronyms following Thiers 2019), besides protologues and type specimens of such species. For morphological descriptions we used a 10-60 $\times$ magnification stereomicroscope. Terminology mostly follows Beentje (2010), but for describing cyathial features, we followed the terminology from the Euphorbia Planetary Biodiversity Inventory group (http://www.euphorbiaceae.org/pages/ about_euphorbia.html) and the most recent studies on the taxonomic classification of the genus (Horn et al. 2012; Yang et al. 2012; Dorsey et al. 2013; Peirson et al. 2013; Riina et al. 2013). The key for the species of Euphorbia sect. Crossadenia is mostly based on Carneiro-Torres et al. (2012), now including E. adenoplicata and the recently described E. riinae (Steinmann 2013). The distribution map was produced in QGIS v. 3.14 (QGIS Development Team 2019), and the proposed conservation status is based on International Union for the Conservation of Nature Guidelines (IUCN 2012), with area of occupancy calculated using GeoCAT (geocat.kew.org/) with a $2 \mathrm{~km}$ cell width.

\section{TAXONOMIC TREATMENT}

Euphorbia adenoplicata O.L.M. Silva \& Cordeiro, sp. nov. TYPE: BRAZIL. Tocantins, Jardim Novo [Ponte Alta do Bom Jesus municipality, according to coordinates], Estrada para Barreiras, ca. $7 \mathrm{~km}$ antes da divisa Tocantins/Bahia, $11^{\circ} 47^{\prime} 42^{\prime \prime}$ S, $46^{\circ} 23^{\prime} 04^{\prime \prime} \mathrm{W}, 21 \mathrm{Jul} .2000$, V. C. Souza et al. 24416 (holotype: ESA!; isotypes: RB!, SP!, SPF!). 
Euphorbia adenoplicata shares with species of E. sect. Crossadenia subsect. Ephedropeplus well developed and persistent leaves, cyathia bearing deeply cleft appendages, and the characteristic seed coat ornamentation (with low and rounded tubercules), but the new species is unique within the section by its plicate cyathial glands, while all the other species in this group have convex to flat cyathial glands.

Herbs or shrubs, up to $40(-50) \mathrm{cm}$ tall; underground system (xylopodium) ca. $1 \mathrm{~cm}$ thick, unbranched; latex white. Stems terete, erect, slightly canaliculate when dried, unbranched or alternately branched; branches green, glabrous, except for the pilose young branches. Leaves alternate on lower nodes and opposite on upper nodes, sessile to subsessile (petioles reaching up to $2 \mathrm{~mm}$ long); stipules lateral and glanduliform, globose, inconspicuous (up to $1 \mathrm{~mm}$ long); leaf blade chartaceous, slightly glaucous, glabrous on both surfaces, slightly discolorous (abaxial surface lighter), elliptic, narrow-elliptic, or oblong, (2.5-)3.5-4.5(-5) × (0.5-)0.8-1(-1.2) cm, persistent, base acute to cuneate, margin entire, apex cuspidate, venation hyphodromous. Cyathia solitary or arranged in terminal pseudodichasia with two lateral branches, sessile to subsessile; peduncle 1-2 $\mathrm{mm}$ long, pilose, with short $(<0.5 \mathrm{~mm}$ long) trichomes; cyathophylls opposite, sessile to subsessile, with two lateral glands and a few scattered hairs at the base, chartaceous, glabrous on both surfaces (except for the base on the adaxial surface), narrow-elliptic or oblong, 1.0-1.5 $\times$ 0.3-0.4 mm, persistent, base acute to cuneate, margin entire, apex cuspidate, venation hyphodromous; involucre campanulate, $2.5-3 \times 4-5.5 \mathrm{~mm}$, actinomorphic, glabrous on the outer surface; involucral lobes triangular, pale to greenish, margin crenate and densely pubescent on the outer surface, with short simple trichomes; cyathial glands 5, light green, transversely elliptic, plicate (i.e. margins folded in the middle portion of the gland, splitting it into two cavities), glabrous on the outer margin, densely pubescent on the inner margin, $0.5-1.0 \times 1.5-2.0(-2.5) \mathrm{mm}$, appendages white, glabrous on both surfaces and deeply cleft into (4-)6-8 lobes, each lobe up to $1.5-2.0(-2.5) \mathrm{mm}$ long. Staminate flowers $40-50$, arranged in 5 cincinni with 8-10 flowers each; bracteoles lanceolate, ciliate; pedicels 1.5-2.0 mm long, filaments $1.5-2 \mathrm{~mm}$ long, anthers ca. $1 \mathrm{~mm}$ wide, dorsifixed, extrorse, vertically dehiscent. Pistillate flowers ca. $3 \mathrm{~mm}$ long, (sometimes reduced to a pistillode, ca. $1 \mathrm{~mm}$ long, with three inconspicuous styles); pedicel up to $1 \mathrm{~mm}$ long; ovary globose, $0.8-1 \times 0.8-1 \mathrm{~mm}$, glabrous; styles $3,2-2.5 \mathrm{~mm}$ long when fully developed, united for $2 / 3$ of their length, entire and revolute at the apex. Capsules 3-lobed, 6-7 × 7-8 mm, glabrous, green; pedicel strongly accrescent, reaching up to $15 \mathrm{~mm}$ long; columella 5-6 mm long; seeds light brown, ovoid, 3.0-3.5 $\times 2.0-2.5 \mathrm{~mm}$, rounded in cross section, testa shallowly tuberculate, covered by a crustaceous, hydrophilic layer, becoming mucilaginous when in contact with water; caruncle absent (the mucronate apex is an extension of the seed coat, characteristic of Euphorbia sect. Crossadenia according to Yang et al. 2012).

Distribution and Ecology-Euphorbia adenoplicata is endemic to Tocantins state, close to the border with Bahia state. It is known from a single locality in the municipality of Ponte Alta do Bom Jesus (Fig. 1), where it grows in cerrado rupestre vegetation, on sandstone outcrops with sandy soils. Elevation of the known populations is around $700-750 \mathrm{~m}$. The species was found in fertile condition in April and July.

The locality where Euphorbia adenoplicata was found, the vicinity of the Serra Geral do Tocantins, is covered in most of its extent by open savannic vegetation, comprising more than 700 ha. However, Tocantins is one of the most undercollected states in Brazil (BFG 2015), and many species are known for this region from just one or a few localities (Antar et al. 2018). Although only known from a single population, the finding of E. adenoplicata may stimulate conservation and botanical sampling efforts in this area, in alignment with the ideas of Wood et al. (2017) and Riina et al. (2018) regarding the description of new taxa from single or a few collections in the Neotropics.

Etymology-The specific epithet refers to the cyathial glands, which are plicate (i.e. margins folded in the middle portion of the gland, splitting it into two cavities; Figs. 2H, 3B).

Conservation Status-Euphorbia adenoplicata is currently known from only two collections from the same locality, which is close to roadsides and large scale soybean fields (Borges and Antar 2016, Antar et al. 2018). Although this locality is subject to uncontrolled fires, the area remains preserved due to its rocky soils, which are unsuitable for agriculture. Nearby rocky areas are currently unexplored and may also contain populations of E. adenoplicata, but we recommend that E. adenoplicata be considered Critically Endangered (CRB2ab[iii]) due to its small area of occupancy $\left(4 \mathrm{~km}^{2}\right)$, a single known population, and the estimated decline of quality of habitat due to anthropization.

Notes-Euphorbia sect. Crossadenia was divided into two subsections following the phylogenetic framework presented by Yang et al. (2012): subsect. Apparicianae Riina, including E. appariciana, E. flaviana, and E. teres, and characterized by cyathia with five glands, exappendiculate or bearing crenulate to dentate appendages; and subsect. Ephedropeplus (Müll. Arg.) Pax, erroneously named as subsect. Sarcodes Riina in Yang et al. (2012), but corrected in Steinmann (2013), which comprises E. crossadenia, E. goyazensis, E. gymnoclada, E. lycioides, E. riinae, E. sarcodes, and E. sessilifolia. The deeply cleft appendages of the cyathial glands along with its well developed, persistent leaves place E. adenoplicata in E. sect. Crossadenia subsect. Ephedropeplus, which now comprises eight species. Whereas most species in subsect. Ephedropeplus have four cyathial glands, both E. adenoplicata and E. gymnoclada Boiss. have five glands.

Among the species of Euphorbia subsect. Ephedropeplus, E. adenoplicata is morphologically closest to E. sarcodes and E. goyazensis in having glabrous stems (except for young branches), leaves, and cyathia, and by having cyathial gland appendages with 4-8 lobes. Also, E. sarcodes and E. goyazensis are the only other species of sect. Crossadenia found in the state of Tocantins. Euphorbia adenoplicata can be distinguished from those by its narrow-elliptic to oblong cyathophylls (vs. orbiculate to wide-elliptic in E. goyazensis and E. sarcodes), cyathial glands with margins folded in the middle portion of the gland, splitting it into two cavities (vs. convex to flat in E. goyazensis and E. sarcodes), and strongly accrescent pedicels in fruit, reaching up to $15 \mathrm{~mm}$ long (vs. up to $8-9 \mathrm{~mm}$ in E. goyazensis and E. sarcodes). The plicate cyathial glands in E. adenoplicata are unique among the species of Euphorbia sect. Crossadenia and the rest of Euphorbia species known from Brazil. However, this character is found in a few species in other non-related clades of Euphorbia, such as E. patula Mill. and E. globosa (Haw.) Sims from E. sect. Anthacanthae subsect. Dactylanthes, and in E. subg. Athymalus (Peirson et al. 2013), indicating independent origins of this feature. 


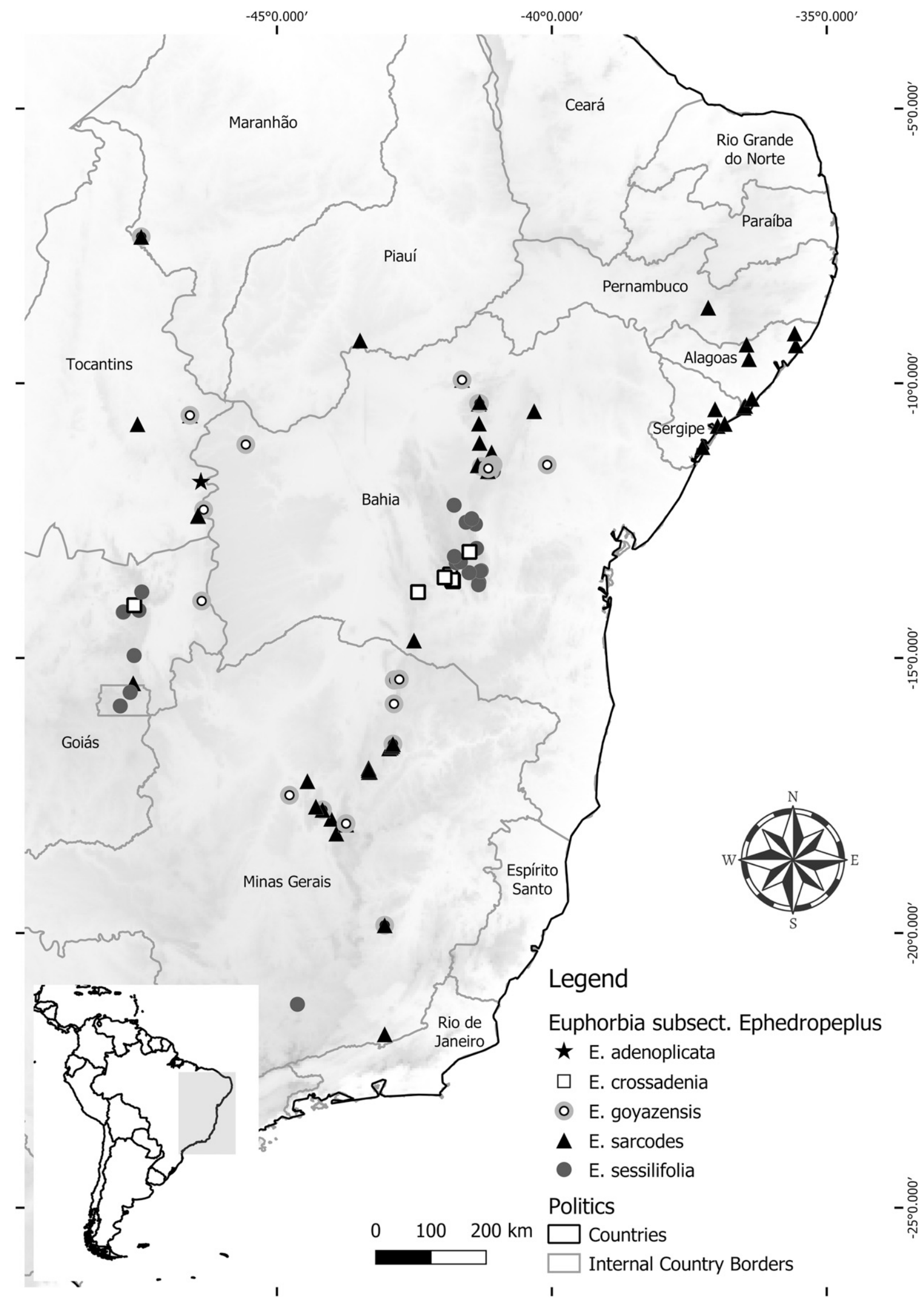

Fig. 1. Distribution of Euphorbia adenoplicata and its morphologically most similar species in E. subsect. Ephedropeplus. 


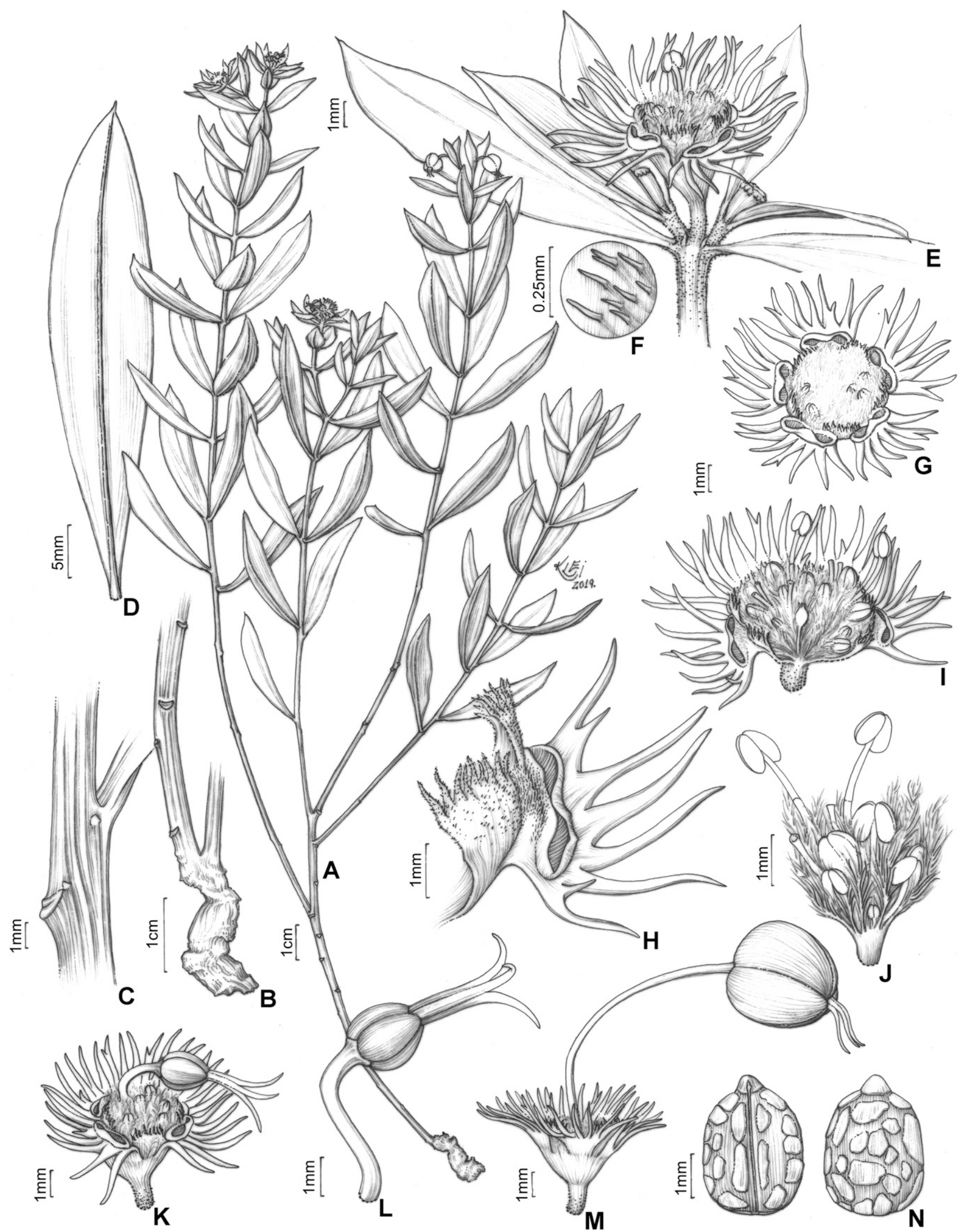

Fig. 2. Euphorbia adenoplicata. A. Habit. B. Detail of the thickened underground system. C. Detail of stem, showing the minute stipules. D. Leaf. E. Apical portion of a branch with a mature cyathium and two lateral young cyathia. F. Detail of indumentum on young branches. G. Apical view of a cyathium showing five cyathial glands. H. Detail of a nectary gland with its deeply cleft appendages and adjacent involucre lobes. I. Open cyathium showing a reduced pistillate flower (i.e. pistillode). J. Staminate cymule with lanceolate, ciliate bracteoles. K. Cyathium with immature fruit emerging. L. Pistillate flower. M. Immature fruit. N. Seeds showing ventral (left) and dorsal (right) view. Illustration by Klei Souza, based on V.C. Souza et al. 24416 (SP). 

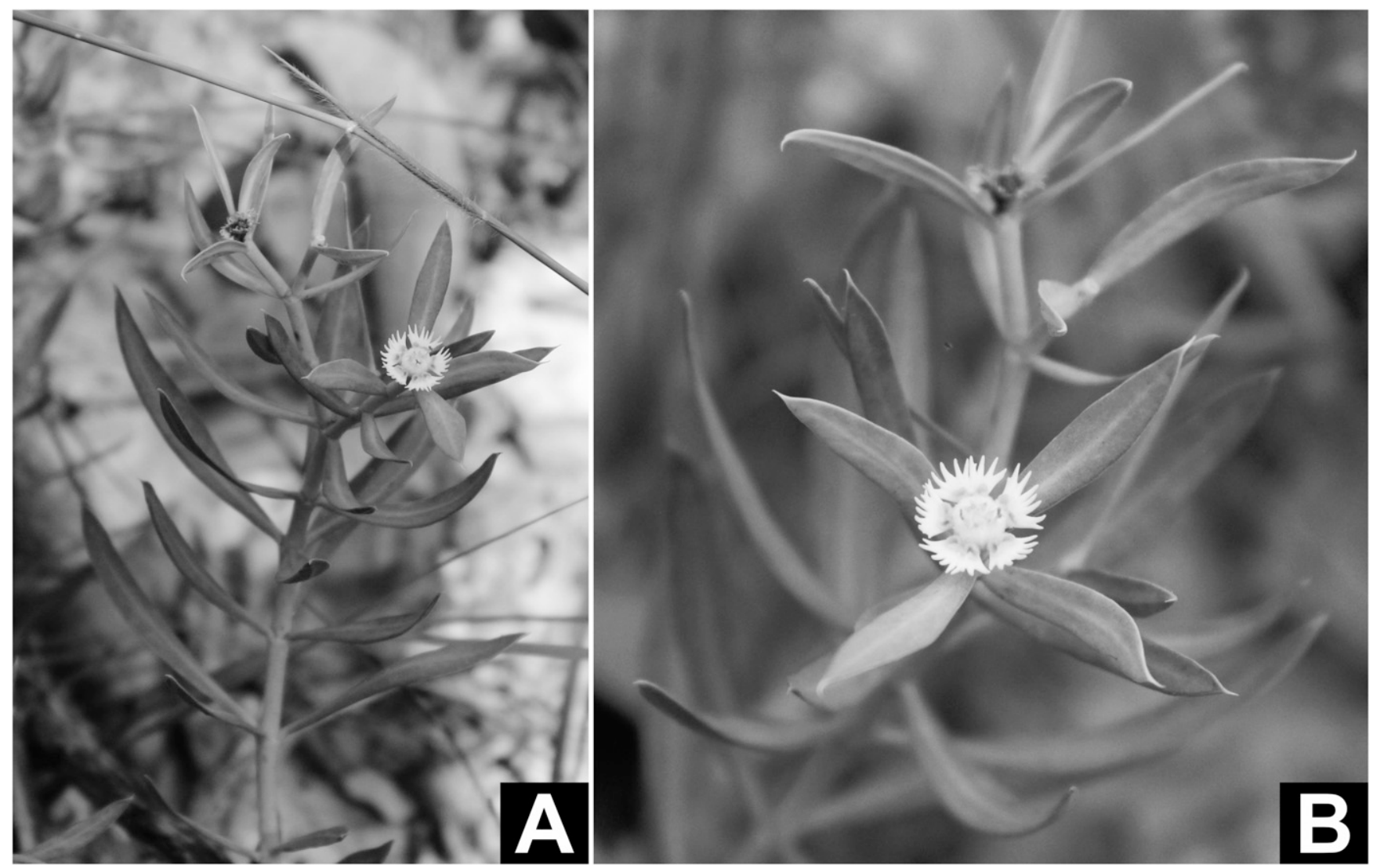

Fig. 3. Euphorbia adenoplicata in the field. A. Habit. B. Detail of a fertile branch with cyathia. Photos: G.M. Antar.

Additional Specimens Examined-Brazil.-Tocantins: Ponte Alta do Bom Jesus, Rodovia TO-040, próximo à divisa com a Bahia. $11^{\circ} 47^{\prime} 44.7^{\prime \prime} \mathrm{S}, 46^{\circ} 22^{\prime} 51^{\prime \prime} \mathrm{W}, 754 \mathrm{~m}, 20$ Apr 2017, G. M. Antar et al. 1556 (SPF!).

\section{Key to the Species of Euphorbia Sect. Crossadenia}

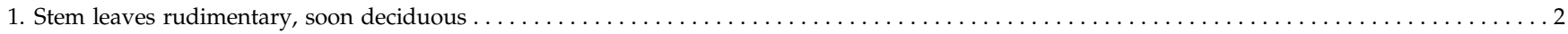

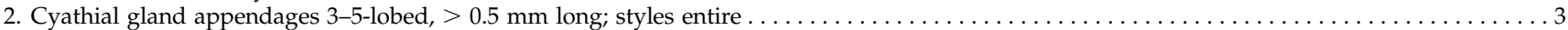

3. Cyathial gland appendages covering the glands; styles $1.2-1.4 \mathrm{~mm}$ long, shorter than the ovary; endemic to Bahia state (Brazil) ...........

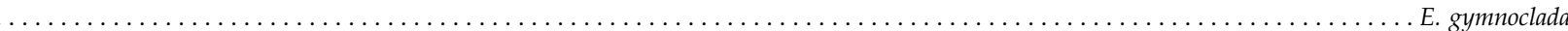

3. Cyathial gland appendages not covering the glands; styles $2.2-3.1 \mathrm{~mm}$ long, longer than the ovary; endemic to Bolivia ........... E. riinae

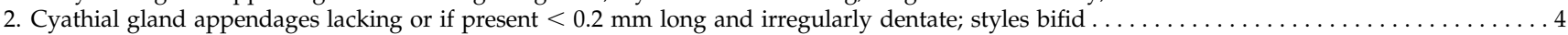

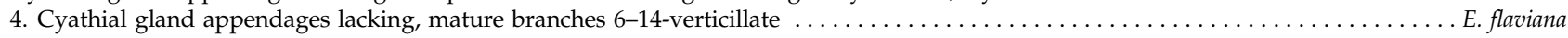

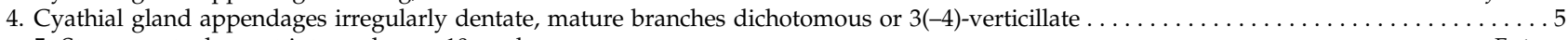

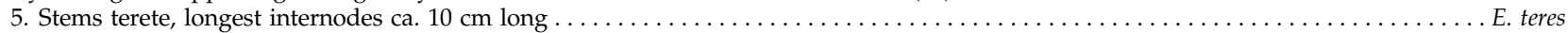

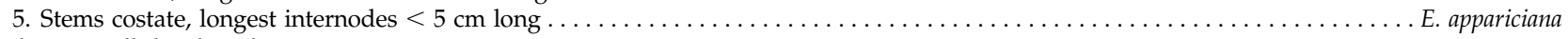

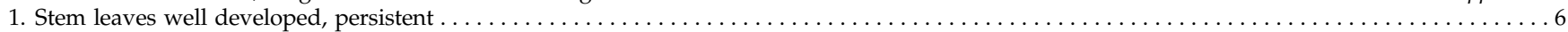

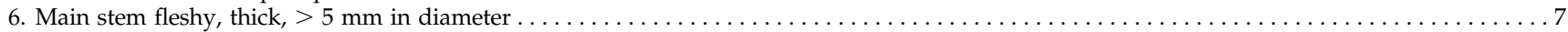

7. Stems glabrous; leaves spirally arranged along branches, with conspicuous internodes; occurring in the Brazilian states of Bahia, Minas Gerais,

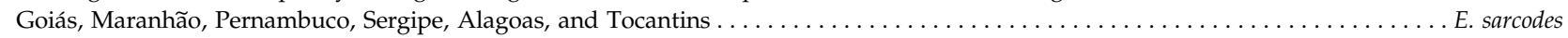

7. Stems pubescent, leaves arranged in brachiblasts (i.e. congested at the apex of branches, with inconspicuous internodes; endemic to the Brazilian

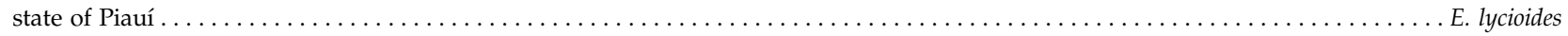

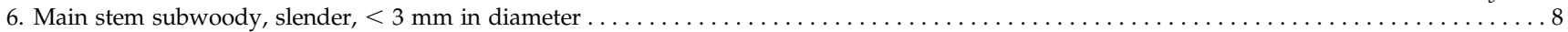

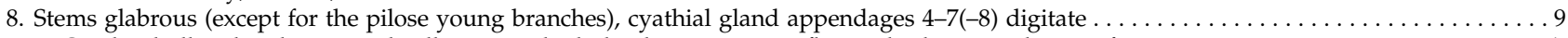
9. Cyathophylls orbiculate to wide-elliptic, cyathial glands 4 , convex to flat, pedicel $<1 \mathrm{~cm}$ long in fruit ............... goyazensis

9. Cyathophylls narrow-elliptic to oblong, cyathial glands 5, plicate (margins folded in the middle portion of the gland, splitting it into two cavities),

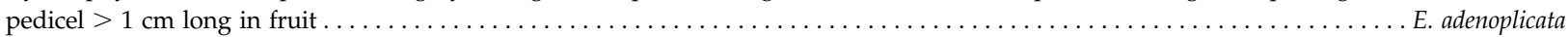

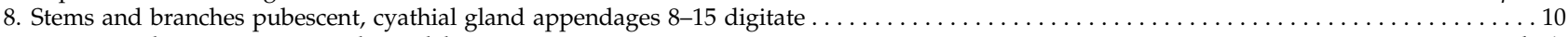

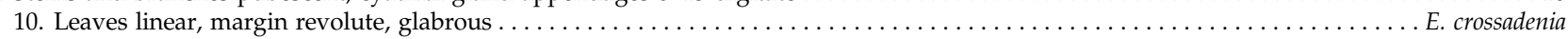

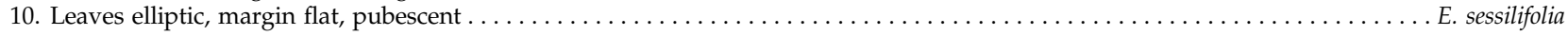

\section{ACKNOWLEDGMENTS}

We thank Klei Souza for providing the illustration; curators of the herbaria ALCB, CEN, ESA, HRB, HUEFS, MBM, RB, SP, SPF, UB, UEC, and UFG; Roberto Santos and Paulo Takeo Sano for help during field work; and the two anonymous reviewers for important considerations on early versions of this manuscript. This study was financed in part by the Coordenação de Aperfeiçoamento de Pessoal de Nível Superior - Brasil (CAPES) - Finance Code 001; OLMS was supported by FAPESP (2013/26501-6 and 2017/061712); GMA by CAPES, ASPT, and Idea Wild; IC by CNPq (309917/2015-8). 


\section{Author Contributions}

OLMS analyzed and described the new species; GMA collected the plant in field. OLMS, GMA, RR, and IC were responsible for the taxonomic discussion, writing, and revision of the manuscript.

\section{Literature Cited}

Alves, R., A. Guimarães, R. Sadala, M. Lira, and N. Silva. 2018. Three new species of Barbacenia (Velloziaceae) from Tocantins, Brazil. Edinburgh Journal of Botany 76: 181-195.

Antar, G. M., M. F. Santos, and P. T. Sano. 2018. Rediscovery and taxonomic reassessment of four angiosperms in the savannas of Jalapão, Central Brazil. Edinburgh Journal of Botany 75: 55-71.

Araújo, D., G. M. Antar, and J. A. Lombardi. 2016. Dioscorea compacta (Dioscoreaceae), a new endangered dwarf species from the Jalapão region, Tocantins, Brazil. Kew Bulletin 71: 27-32.

Beentje, H. 2010. The Kew Plant Glossary: An Illustrated Dictionary of Plant Terms. London: Kew Publishing Royal Botanical Gardens, Kew.

BFG - The Brazil Flora Group. 2015. Growing knowledge: An overview of seed plant knowledge in Brazil. Rodriguésia 66: 1085-1113.

Boissier, E. 1860. Centuria Euphorbiarum. Paris: B. Hermann, Leipzig \& J.B. Bailliére.

Boissier, E. 1862. Euphorbieae. Pp. 3-188 in Prodromus Systematics Universalis Regni Vegetabilis vol. 15, ed. A. L. P. P. de Candolle. Paris: Victor Masson.

Borges, L. M. and G. M. Antar. 2016. Four they are! Broadening the description of Mimosa flabellifolia (Leguminosae Mimosoideae), a rare species from the Brazilian Cerrado. Phytotaxa 243: 155-162.

Carneiro-Torres, D. S., I. Cordeiro, A. M. Giulietti, and R. Riina. 2012. Euphorbia flaviana, a new species from the inselbergs of Bahia (Brazil) and lectotypification of E. crossadenia. Systematic Botany 37: 688-693.

Carrillo-Reyes, P. and V. W. Steinmann. 2011. Two new species of Euphorbia sect. Nummulariopsis (Euphorbiaceae) from South America. Anales del Jardin Botanico de Madrid 68: 167-173.

Devecchi, M. F. and J. R. Pirani. 2015. A new species of Simaba sect. Grandiflorae (Simaroubaceae) from Jalapão region, Tocantins, Brazil. Phytotaxa 227: 167-174.

Dorsey, B. L., T. Haevermans, X. Aubriot, J. J. Morawetz, R. Riina, V. W. Steinmann, and P. E. Berry. 2013. Phylogenetics, morphological evolution, and classification of Euphorbia subgenus Euphorbia. Taxon 62: 291-315.

Flora do Brasil. 2020 [under construction]. 2019. Flora do Brasil 2020 - Algas, Fundos e Plantas. Jardim Botânico do Rio de Janeiro. Available from: http:/ / floradobrasil.jbrj.gov.br/ (last accessed September 2019).

Horn, J. W., B. W. van Ee, J. J. Morawetz, R. Riina, V. W. Steinmann, P. E. Berry, and K. J. Wurdack. 2012. Phylogenetics and the evolution of major structural characters in the giant genus Euphorbia L. (Euphorbiaceae). Molecular Phylogenetics and Evolution 63: 305-326.

Hurbath, F., B. S. S. Leal, O. L. M. Silva, C. Palma-Silva, and I. Cordeiro. 2018. A new species and molecular phylogeny of Brazilian succulent Euphorbia sect. Brasilienses. Systematics and Biodiversity 16: 658-667.

IUCN. 2012. IUCN red list categories and criteria version 3.1. Ed. 2. Gland, Switzerland and Cambridge, UK: IUCN.

Külkamp, J., O. L. M. Silva, E. Valduga, J. R. V. Iganci, I. Cordeiro, and J. F. A. Baumgratz. 2018. First record of Euphorbia pedersenii Subils (Euphorbiaceae) for Brazil. Phytotaxa 379: 287-292.
Machado, M. C. and A. Hofacker. 2008. Euphorbia teres (Euphorbiaceae): Eine neue sukkulente Art aus Brasilien. Kakteen und andere Sukkulenten 59: 150-154.

Marques, O., I. Cordeiro, and R. Riina. 2016. Lovers of sandy habitats and rocky outcrops: Euphorbia section Crossadenia. Euphorbia World 12: 31-39.

Mendoza, J. M. and M. L. L. Martins. 2018. Distinctive new species of Manihot (Euphorbiaceae) from Brazil. Novon 26: 59-65.

Mittermeier, R. A., W. R. Turner, F. W. Larsen, T. M. Brooks, and C. Gascon. 2011. Global biodiversity conservation: The critical role of hotspots. Pp 3-22 in Biodiversity Hotspots, eds. E. Zachos and J. C. Habel. London: Springer Publishers.

Moreira, A. L. C., G. M. Antar, R. Simão-Bianchini, and T. B. Cavalcanti. 2017. Contribution to the knowledge of Bonamia (Convolvulaceae) in Brazil: A new species and a new occurrence. Phytotaxa 306: 146-152.

Morim, M. P. and E. M. N. Lughadha. 2015. Flora of Brazil Online: Can Brazil's botanists achieve their 2020 vision? Rodroguésia 66: 1115-1135.

Oliveira, U., B. S. Soares-Filho, A. P. Paglia, A. D. Brescovit, C. J. B. Carvalho, D. P. Silva, D. P. Rezende, F. S. F. Leite, J. A. N. Batista, J. P. P. P. Barbosa, J. R. Stehmann, J. S. Ascher, M. F. Vasconcelos, P. De Marco, P. Löwenberg-Neto, V. G. Ferro, and A. J. Santos. 2017. Biodiversity conservation gaps in the Brazilian protected areas. Scientific Reports 7: 9141.

Peirson, J. A., P. V. Bruyns, R. Riina, J. J. Morawetz, and P. E. Berry. 2013. A molecular phylogeny and classification of the largely succulent and mainly African Euphorbia subg. Athymalus (Euphorbiaceae). Taxon 62: 1178-1199.

QGIS Development Team. 2019. QGIS Geographic Information System. Open Source Geospatial Foundation Project. http://qgis.osgeo.org (last accessed September 2019).

Riina, R., J. A. Peirson, D. V. Geltman, J. Molero, B. Frajman, A. Pahlevani, L. Barres, J. J. Morawetz, Y. Salmaki, S. Zarre, A. Kryukov, P. V. Bruyns, and P. E. Berry. 2013. A worldwide molecular phylogeny and classification of the leafy spurges, Euphorbia subgenus Esula (Euphorbiaceae). Taxon 62: 316-342.

Riina, R., P. E. Berry, R. S. Secco, W. Meier, and M. B. R. Caruzo. 2018. Reassessment of Croton sect. Cleodora (Euphorbiaceae) points to the Amazon Basin as its main center of diversity. Annals of the Missouri Botanical Garden 103: 330-349.

Silva, O. L. M. and I. Cordeiro. 2015. Euphorbia sarcoceras, a new species of Euphorbia sect. Alectoroctonum from Brazil. Systematic Botany 40: 962-967.

Steinmann, V. W. 2013. Three new species of Euphorbia subg. Chamaesyce (Euphorbiaceae) from Bolivia. Phytotaxa 114: 23-32.

Strassburg, B. B. N., T. Brooks, R. Feltran-Barbieri, A. Iribarrem, R. Crouzeilles, R. Loyola, A. E. Latawiec, F. J. B. O. Filho, C. A. M. Scaramuzza, F. R. Scarano, B. Soares-Filho, and A. Balmford. 2017. Moment of truth for the Cerrado hotspot. Nature Ecology and Evolution 1: 0099

Wood, J. R. I., P. Muñoz-Rodriguez, R. Degen, and R. W. Scotland. 2017. New species of Ipomoea (Convolvulaceae) from South America. PhytoKeys 88: 1-38.

Thiers, B. 2019 [continuously updated]. Index Herbariorum: A global directory of public herbaria and associated staff. New York Botanical Garden's Virtual Herbarium. http://sweetgum.nybg.org/science/ ih/ (last accessed September 2019).

Yang, Y., R. Riina, J. J. Morawetz, T. Haevermans, X. Aubriot, and P. E. Berry. 2012. Molecular phylogenetics and classification of Euphorbia subgenus Chamaesyce (Euphorbiaceae). Taxon 61: 764-789. 